\title{
23. HYDROCARBONS AS INDICATORS FOR PROVENANCE AND THERMAL HISTORY OF ORGANIC MATTER IN LATE CENOZOIC SEDIMENTS FROM HOLE 909C, FRAM STRAIT ${ }^{1}$
}

\author{
Joachim Rinna, ${ }^{2}$ Jürgen Rullkötter, ${ }^{2,3}$ and Rüdiger Stein ${ }^{4}$
}

\begin{abstract}
Miocene to Pliocene deep-sea sediments recovered during Ocean Drilling Program Leg 151 in Hole 909C in the Fram Strait (North Atlantic-Arctic Gateway) contain between $0.5 \%$ and $1.6 \%$ organic carbon, which is mostly of terrigenous origin as far as it is represented by the nonaromatic hydrocarbons in the solvent extractable fraction. This is illustrated, for example, by the occurrence of pentacyclic triterpenes of higher plant origin and the dominance of $\mathrm{C}_{29}$ steroid hydrocarbons. Molecular indicators show some variation in the supply of the organic material, for example, by the specific occurrence of two isomeric 24,28dinor-lupanes in two Miocene horizons. Diagenetic evolution of the organic matter is obvious in the nonaromatic hydrocarbon fractions by the disappearance of regular sterenes, isomerization of diasterenes at C-20, appearance of regular and rearranged steranes, and the increase of the neo-hop-13(18)-ene/hop-17(21)-ene ratio in the deeper part of the section. Despite the apparently high geothermal gradient, the zone of thermal cracking according to biomarker analysis has not been reached by drilling. The low maturity of the organic matter, observed by bulk and molecular organic geochemical parameters, indicates that the sudden increase of low-molecular-weight hydrocarbon $\left(\mathrm{C}_{4}-\mathrm{C}_{7}\right)$ concentrations at the bottom of Hole $909 \mathrm{C}$ is due to migration of these compounds from deeper sediments with more mature organic matter.
\end{abstract}

\section{INTRODUCTION}

Ocean Drilling Program Site 909 is located in the center of the Fram Strait at the Greenland-Spitsbergen sill terrace immediately north of the Hovgaard Ridge (Fig. 1), a gently elevated area protected against massive (turbiditic) sediment influx from the Svalbard and Greenland Margins. Hole 909C was drilled in a water depth of about $3580 \mathrm{~m}$ to a terminal depth of $1061.8 \mathrm{mbsf}$. The hole had to be abandoned for safety reasons because of the stepwise increase of hydrocarbon concentrations at the bottom of the hole (Shipboard Scientific Party, 1995; Stein et al., 1995).

According to the initial core descriptions (Shipboard Scientific Party, 1995), the drilled sediment section consists of gray to dark gray clays to silty clays with varying amounts of sand and/or dropstones. Bioturbation is pervasive except in the lowermost part of the hole where laminated intervals, interrupted by slumps, occur. Based on texture, composition, and sedimentary structures, the sedimentary sequence was subdivided in three lithologic units. Unit I consists of gray to dark gray interbedded clays, silty clays, and clayey muds with varying amounts of dropstones. Coal fragments are common in many horizons. The Pliocene to Quaternary sediments span the depth range from $248.8 \mathrm{mbsf}$ to the seafloor. Miocene to Pliocene sediments in Unit II (248.8-518.3 mbsf) predominantly comprise dark silty clays and clayey silts with pyrite. The extent of layering increases below 499 mbsf, and bioturbation is minimal in the layered intervals, particularly where fine laminations occur. Unit III (518.3-1061.8 mbsf; Miocene) is divided into two subunits. The upper subunit consists of dark gray silty clays, clayey silts, and muds, and is characterized by

'Thiede, J., Myhre, A.M., Firth, J.V., Johnson, G.L., and Ruddiman, W.F. (Eds.), 1996. Proc. ODP, Sci. Results, 151: College Station, TX (Ocean Drilling Program). ${ }^{2}$ Institut für Chemie und Biologie des Meeres, Carl von Ossietzky Universität Oldenburg, Postfach 2503, D-26111 Oldenburg, Federal Republic of Germany.

'Correspondence author: J.Rullkoetter@ogc.icbm.uni-oldenburg.de

${ }^{4}$ Alfred-Wegener-Institut für Polar- und Meeresforschung, ColumbusstraBe, D-27568 Bremerhaven, Federal Republic of Germany. meter-scale alternations of bioturbated layers and laminations. The lower subunit comprises dark gray silty clays, clayey silts, and clayey and silty muds. Several intervals are folded and otherwise deformed, and fossils of benthic organisms are common.

Temperature measurement using the logging tools yielded a value of $44.5^{\circ} \mathrm{C}$ at $1013 \mathrm{mbsf}$. This, together with the mudline temperature

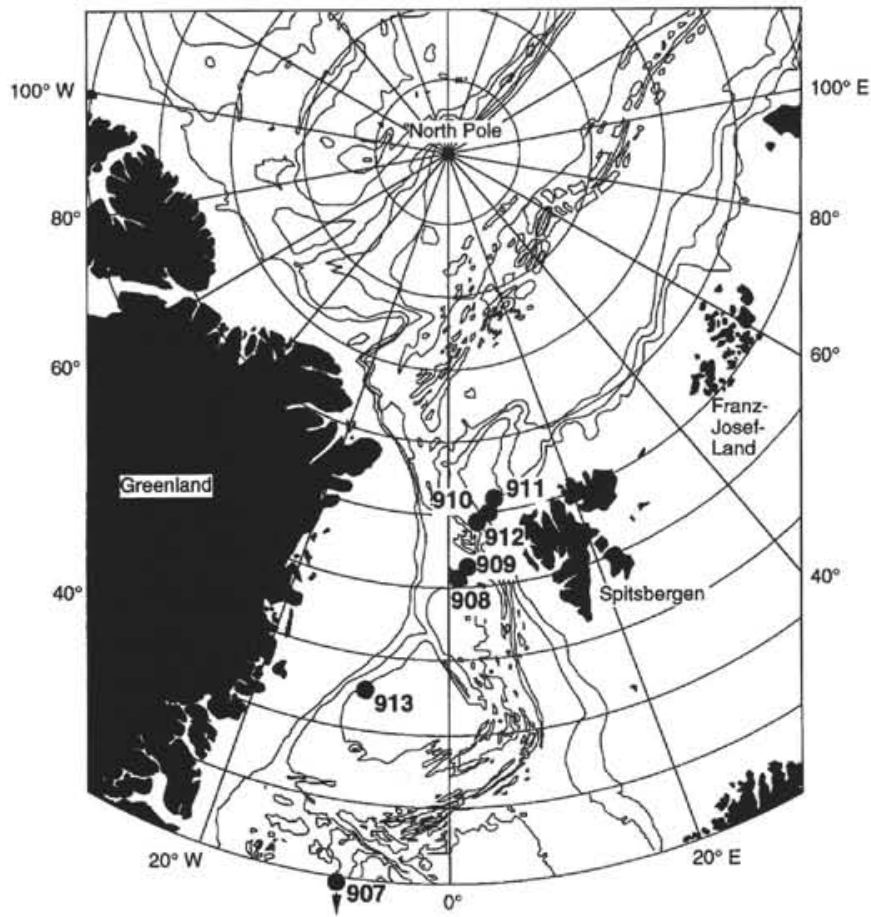

Figure 1. Map showing the drilling location of Site 909 in the Fram Strait, North Atlantic-Arctic Gateway (Stein et al., 1995). 
of $-1.45^{\circ} \mathrm{C}$, relates to a geothermal gradient of $45.4^{\circ} \mathrm{C} / \mathrm{km}$ that is considered a minimum value because circulated cold seawater will have influenced the (single) temperature measurement (Shipboard Scientific Party, 1995). From a series of temperature measurements with the Adara tool in shallow Hole 909A (deepest data point at 84.4 mbsf), a geothermal gradient of $97.6^{\circ} \mathrm{C} / \mathrm{km}$ was calculated (Shipboard Scientific Party, 1995), whereas Stein et al. (1995), in their interpretation of volatile hydrocarbon concentrations, use an "uncorrected" geothermal gradient of $88^{\circ} \mathrm{C} / \mathrm{km}$.

Shipboard measurements revealed total organic carbon (TOC) concentrations in Hole 909C sediments varying mostly between $0.8 \%$ and $1.5 \%$ with systematically lower values in the shallowest $100 \mathrm{~m}$ of the section and occasional higher values exceeding $1.5 \%$ throughout the entire section (Stein et al., 1995; Shipboard Scientific Party, 1995). Hydrogen indices from Rock-Eval pyrolysis varied between 50 and $100 \mathrm{mg}$ hydrocarbons $(\mathrm{HC} / \mathrm{g}$ TOC indicating strongly oxidized and/or terrigenous organic matter as the dominant organic material. Only in the interval between about $980 \mathrm{mbsf}$ and the bottom of Hole $909 \mathrm{C}$ did the hydrogen indices range between 100 and 200 $\mathrm{mg} \mathrm{HC} / \mathrm{g}$ TOC. Besides abundant methane, most likely of microbial origin, elevated concentrations of higher hydrocarbons $\left(\mathrm{C}_{4}-\mathrm{C}_{7}\right)$ were detected by shipboard headspace analysis in the deeper part of Hole $909 \mathrm{C}$ (below $700 \mathrm{mbsf}$ ) with a sudden stepwise increase (factor 5-10 for single compounds) of straight-chain and branched alkanes below $1000 \mathrm{mbsf}$. Due to low temperatures of maximum pyrolysis yield and low production indices from Rock-Eval pyrolysis, the indigenous organic matter during Leg 151 was considered immature and the hydrocarbons were believed to have migrated from a deeper part of the section with more mature organic matter (Stein et al., 1995).

The objective of this study is to monitor the diagenetic development of high-molecular-weight hydrocarbons under the influence of a high geothermal heat flow at Site 909. This information may be useful to support the initial shipboard interpretation of the origin of the light hydrocarbons (Stein et al., 1995), and to provide information on the origin of the organic matter in the Fram Strait based on nonaromatic hydrocarbon distributions analyzed by gas chromatography (GC) and combined gas chromatography-mass spectrometry (GCMS) as a contribution toward a sedimentary budget through time for this area.

\section{ANALYTICAL METHODS}

We investigated 14 core samples from Hole 909C. Information on sub-bottom depth, lithology, and biostratigraphic age (Shipboard Scientific Party, 1995) is compiled in Table 1. All of the samples were extracted, the total extracts separated into group-type fractions, and the nonaromatic hydrocarbon fractions analyzed by GC and GC-MS.

After freeze-drying and grinding, the sediments were analyzed for total organic carbon content by combustion in a Ströhlein Coulomat 702 apparatus. Solvent extraction of quantities between 4 and $19.4 \mathrm{~g}$ dry sediment were performed in an ultrasonic bath with dichloromethane $/ 1 \%$ methanol $(\mathrm{v} / \mathrm{v})$ in four steps, first with $50 \mathrm{~mL}$ (15 min) and then three times with $30 \mathrm{~mL}(15 \mathrm{~min} / 10 \mathrm{~min} / 10 \mathrm{~min})$. After decanting, filtration, and the addition of internal standards (squalane,

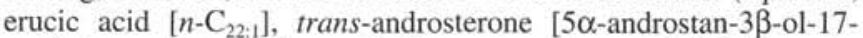
one], $5 \alpha$-androstan-17-one; the latter three were added for later investigation of the heterocompounds), the solvent of the combined extracts was reduced to a volume of approximately $2 \mathrm{~mL}$ by rotary evaporation. The remaining solvent was removed in a stream of nitrogen at mild temperature $\left(30^{\circ}-35^{\circ} \mathrm{C}\right)$. Extract yields were determined gravimetrically.

After splitting extracts in half, elemental sulfur was removed with activated copper filings, and then the hexane-insoluble fractions (asphaltenes) were precipitated. The hexane-soluble portions were separated by medium-pressure liquid chromatography (MPLC; Radke et
Table 1. Lithology, age, and organic carbon content of sediments from Hole 909C, Fram Strait.

\begin{tabular}{|c|c|c|c|c|}
\hline $\begin{array}{l}\text { Core, section, } \\
\text { interval }(\mathrm{cm})\end{array}$ & $\begin{array}{l}\text { Depth } \\
\text { (mbsf) }\end{array}$ & $\begin{array}{l}\text { Lithology } \\
\text { (mg/g TOC) }\end{array}$ & Age & $\begin{array}{l}\text { TOC } \\
(\%)\end{array}$ \\
\hline \multicolumn{5}{|l|}{ 151-909C- } \\
\hline SR-1, 17-19 & 123.78 & Very dark gray silty clay & Pliocene & 0.53 \\
\hline $10 \mathrm{R}-4,49-51$ & 176.90 & Dark gray silty clay & Pliocene & 0.75 \\
\hline $29 \mathrm{R}-5,49-51$ & 341.40 & Very dark gray silty clay & Pliocene & 1.53 \\
\hline $37 \mathrm{R}-5,49-51$ & 438.20 & Very dark gray silty clay & $\begin{array}{l}\text { Miocene- } \\
\text { Pliocene }\end{array}$ & 1.25 \\
\hline $48 \mathrm{R}-6,48-51$ & 545.71 & Very dark gray silty clay & $\begin{array}{l}\text { Miocene- } \\
\text { Pliocene }\end{array}$ & 1.14 \\
\hline $54 \mathrm{R}-1,50-52$ & 596.01 & Very dark gray silty clay & Miocene & 1.21 \\
\hline $61 \mathrm{R}-5,49-51$ & 669.50 & Very dark gray silty clay & Miocene & 1.03 \\
\hline $71 \mathrm{R}-2,49-51$ & 761.30 & Very dark gray silty clay & Miocene & 0.92 \\
\hline $84 \mathrm{R}-3,126-128$ & 889.07 & Very dark gray silty clay & Miocene & 1.05 \\
\hline $88 \mathrm{R}-1,125-126$ & 924.66 & Very dark gray silty clay & Miocene & 0.83 \\
\hline $92 \mathrm{R}-1,124-126$ & 963.35 & Very dark gray silty clay & Miocene & 0.84 \\
\hline $94 \mathrm{R}-1,124-126$ & 982.55 & $\begin{array}{l}\text { Very dark gray to black silty } \\
\text { clay }\end{array}$ & Miocene & 1.12 \\
\hline $102 \mathrm{R}-1,128-130$ & 1055.49 & $\begin{array}{l}\text { Very dark to dark gray } \\
\text { carbonate-bearing clayey } \\
\text { mud }\end{array}$ & early Miocene & 1.48 \\
\hline $103 R-1,124-126$ & 1059.25 & Very dark gray silty clay & early Miocene & 1.33 \\
\hline
\end{tabular}

Note: TOC reflects average of two measurements.

al., 1980) into fractions of different polarities (nonaromatic hydrocarbons, aromatic hydrocarbons, and polar compounds [NSO fraction]). All fractions were worked up as described for the whole extracts and weighed; the sulfur contents were calculated by difference after the desulfurized total extracts were weighed.

Gas chromatography was carried out on a Hewlett-Packard 5890 Series II instrument equipped with a temperature-programmed cold injection system (Gerstel) and a fused silica capillary column (J\&W DB-5, length $=30 \mathrm{~m}$, inner diameter $=0.25 \mathrm{~mm}$, and film thickness $=0.25 \mu \mathrm{m})$. Helium was used as the carrier gas, and the temperature of the oven was programmed from $60^{\circ} \mathrm{C}\left(1 \mathrm{~min}\right.$ isothermal) to $305^{\circ} \mathrm{C}$ ( $50 \mathrm{~min}$ isothermal) at a rate of $3^{\circ} \mathrm{C} / \mathrm{min}$.

GC-MS studies were performed with the same type of gas chromatograph (helium as the carrier gas) and a temperature program from $60^{\circ}\left(1 \mathrm{~min}\right.$ isothermal) to $300^{\circ} \mathrm{C}(50 \mathrm{~min}$ isothermal) at a rate of $3^{\circ} \mathrm{C} / \mathrm{min}$. The gas chromatograph was coupled to a Finnigan SSQ $710 \mathrm{~B}$ mass spectrometer operated at $70 \mathrm{eV}$. Compound identifications are based on comparison of relative gas chromatographic retention times and mass spectra with those reported in the literature.

\section{RESULTS AND DISCUSSION Bulk Composition}

The organic carbon contents of the 14 investigated samples are listed in Table 1 . The data vary between $0.5 \%$ and $1.6 \%$, and, thus, they are in good agreement with the shipboard measurements (Stein et al., 1995; Shipboard Scientific Party, 1995). The lowest organic carbon contents were determined for the two shallowest (Pliocene) sediments of the series, but otherwise there is no systematic trend with depth or age.

Extract yields and gross compositions of the extracts after precipitation and chromatographic separation are shown in Table 2. Corrected for elemental sulfur, the extract yields range between $11.1 \mathrm{mg} /$ $\mathrm{g}$ TOC and $31.6 \mathrm{mg} / \mathrm{g}$ TOC. Given the low absolute amounts of extract and low accuracy of gravimetric determination, these values are typical of sediments with immature organic matter (e.g., Rullkötter et al., 1981). There is also no significant rise in the deepest sediments close to the terminal depth of Hole 909C, where elevated concentrations of light hydrocarbons were detected during drilling. Obviously, migration of $\mathrm{C}_{15+}$ hydrocarbons has not occurred to an extent that it is recognizable by extract yield. 
The relative distributions of the gross chromatographic fractions, obtained by fractionation of the total extracts, are dominated by heterocompounds (NSO fraction), which account for $44 \%$ to $78 \%$ of the total extracts (Table 2; Fig. 2). The portion of asphaltenes varies between $10 \%$ and $40 \%$, with a maximum in Samples 151-909C-88R-1, $125-126 \mathrm{~cm}$, to $94 \mathrm{R}-1,124-126 \mathrm{~cm}$. The nonaromatic hydrocarbons represent $9 \%$ to $22 \%$ of the total extracts, whereas the amount of aromatic hydrocarbons varies from $<5 \%$ to $11 \%$. The nonaromatic hydrocarbon portion may be slightly higher than in deep-sea sediments dominated by marine organic matter (e.g., Rullkötter et al., 1981), but this is explained by the higher biogenic abundance of hydrocarbons in terrigenous organic matter, which appears to be the dominant organic matter type in Hole 909C sediments (see discussion of molecular composition below). There is no increase in the proportion of nonaromatic hydrocarbons near the bottom of the hole, which would indicate an onset of thermal organic matter cracking. Elemental sulfur occurs in all solvent extracts, but in the two deepest sediments analyzed (Samples 151-909C-102R-1, 128-130 cm, and 103R-1, 124$126 \mathrm{~cm}$ ), the amount of extractable elemental sulfur is as high as $89 \%$ and $86 \%$ of total extract, respectively, indicating that at least some labile organic matter reached the ocean floor to support microbial sulfate reduction in general but obviously more significantly during Oligocene-Miocene times.

\section{Molecular Investigation of Nonaromatic Hydrocarbons n-Alkanes}

Figure 3 shows gas chromatograms of eight selected nonaromatic hydrocarbon fractions. An unresolved complex mixture (UCM) increases with depth. This indicates the increasing complexity and abundance of the polycyclic nonaromatic hydrocarbons relative to the $n$-alkanes. The $n$-alkane distributions are dominated by longchain homologs typical of epicuticular waxes of higher land plants (Eglinton et al., 1962), although long-chain $n$-alkanes may also derive from $n$-alkadiene precursors in Botryococcus braunii algae (Lichtfouse et al., 1994). Since there is no other indication of a lacustrine algal contribution to the organic matter in Hole 909C sediments, a higher plant origin of the $n$-alkanes appears more likely. The max-

Table 2. Extract yield, group-type composition, and molecular ratios of biological markers for sediments from Hole 909C, Fram Strait.

\begin{tabular}{|c|c|c|c|c|c|c|c|c|c|c|}
\hline $\begin{array}{l}\text { Core, section, } \\
\text { interval }(\mathrm{cm})\end{array}$ & $\begin{array}{l}\text { Depth } \\
\text { (mbsf) }\end{array}$ & $\begin{array}{l}\text { Extract yield }^{\mathrm{a}} \\
\text { (mg/g TOC) }\end{array}$ & $\begin{array}{l}\text { Asph. } \\
(\%)\end{array}$ & $\begin{array}{c}\text { Nonaromatic } \\
\text { hydrocarbons } \\
\text { (\%) }\end{array}$ & $\begin{array}{c}\text { Aromatic } \\
\text { hydrocarbons } \\
(\%)\end{array}$ & $\begin{array}{l}\text { Hetero- } \\
\text { compounds } \\
\text { (\%) }\end{array}$ & $\begin{array}{l}\text { Diasterene } \\
\text { ratio }^{\mathrm{b}}\end{array}$ & $\begin{array}{l}\mathrm{Pr} / \mathrm{Ph} \\
\text { ratio }\end{array}$ & $\begin{array}{l}\text { Hopene } \\
\text { ratio }^{e}\end{array}$ & $\begin{array}{l}17 \alpha-\text { Hopane } \\
\text { epimer ratio }^{d}\end{array}$ \\
\hline \multicolumn{11}{|l|}{$151-909 \mathrm{C}$ - } \\
\hline $5 \mathrm{R}-1,17-19$ & 123.78 & 16.8 & 22 & 22 & 11 & 44 & 0.34 & 0.07 & 0.61 & 0.21 \\
\hline $10 \mathrm{R}-4,49-51$ & 176.90 & 31.6 & 11 & 15 & 86 & 2 & ND & ND & 0.47 & 0.23 \\
\hline $29 \mathrm{R}-5,49-51$ & 341.40 & 16.2 & 20 & 10 & $<5$ & 65 & 0.34 & 1.36 & 0.42 & 0.17 \\
\hline $37 \mathrm{R}-5,49-51$ & 438.20 & 20.0 & 20 & 11 & 6 & 59 & 0.34 & 0.15 & 0.36 & 0.24 \\
\hline $48 \mathrm{R}-6,48-51$ & 545.71 & 11.7 & 18 & 9 & $<5$ & 63 & 0.17 & 0.93 & 0.27 & 0.34 \\
\hline $54 \mathrm{R}-1,50-52$ & 596.01 & 29.2 & 22 & 12 & $<5$ & 63 & 0.20 & ND & 0.28 & 0.31 \\
\hline $61 \mathrm{R}-5,49-51$ & 669.50 & 13.8 & 14 & 10 & $<5$ & 71 & 0.19 & 0.81 & 0.34 & 0.22 \\
\hline $71 R-2,49-51$ & 761.30 & 13.9 & 12 & 12 & $<5$ & 75 & 0.24 & 1.01 & 0.38 & 0.15 \\
\hline $84 \mathrm{R}-3,126-128$ & 889.07 & 14.9 & 10 & 11 & $<5$ & 78 & 0.43 & 1.66 & 0.82 & 0.10 \\
\hline $88 \mathrm{R}-1,125-126$ & 924.66 & 11.3 & 30 & 16 & $<5$ & 50 & 0.42 & 1.51 & 0.87 & 0.14 \\
\hline $92 \mathrm{R}-1,124-126$ & 963.35 & 28.3 & 41 & 9 & $<5$ & 45 & 0.42 & 0.77 & 0.87 & 0.10 \\
\hline $94 \mathrm{R}-1,124-126$ & 982.55 & 14.8 & 30 & 9 & $<5$ & 55 & 0.45 & 1.03 & 0.87 & 0.14 \\
\hline $102 \mathrm{R}-1,128-130$ & 1055.49 & 11.1 & 12 & 12 & 6 & 69 & 0.44 & 2.26 & 0.83 & 0.15 \\
\hline $103 \mathrm{R}-\mathrm{I}, 124-126$ & 1059.25 & 25.2 & 14 & 15 & 8 & 62 & 0.44 & 2.15 & 0.91 & 0.13 \\
\hline
\end{tabular}

Notes: Asph. $=$ asphaltenes. $\mathrm{ND}=$ not detected.

${ }^{2}$ Corrected for elemental sulfur.

${ }^{b} 20 S /(20 S+20 R)$-diacholest-13(17)-enes.

'neo-hop-13(18)-ene/(neo-hop-13(18)-ene+hop-17(21)-ene).

${ }^{d} 22 \mathrm{~S} /(22 \mathrm{~S}+22 \mathrm{R})$ of $\mathrm{C}_{31} 17 \alpha$-hopanes.

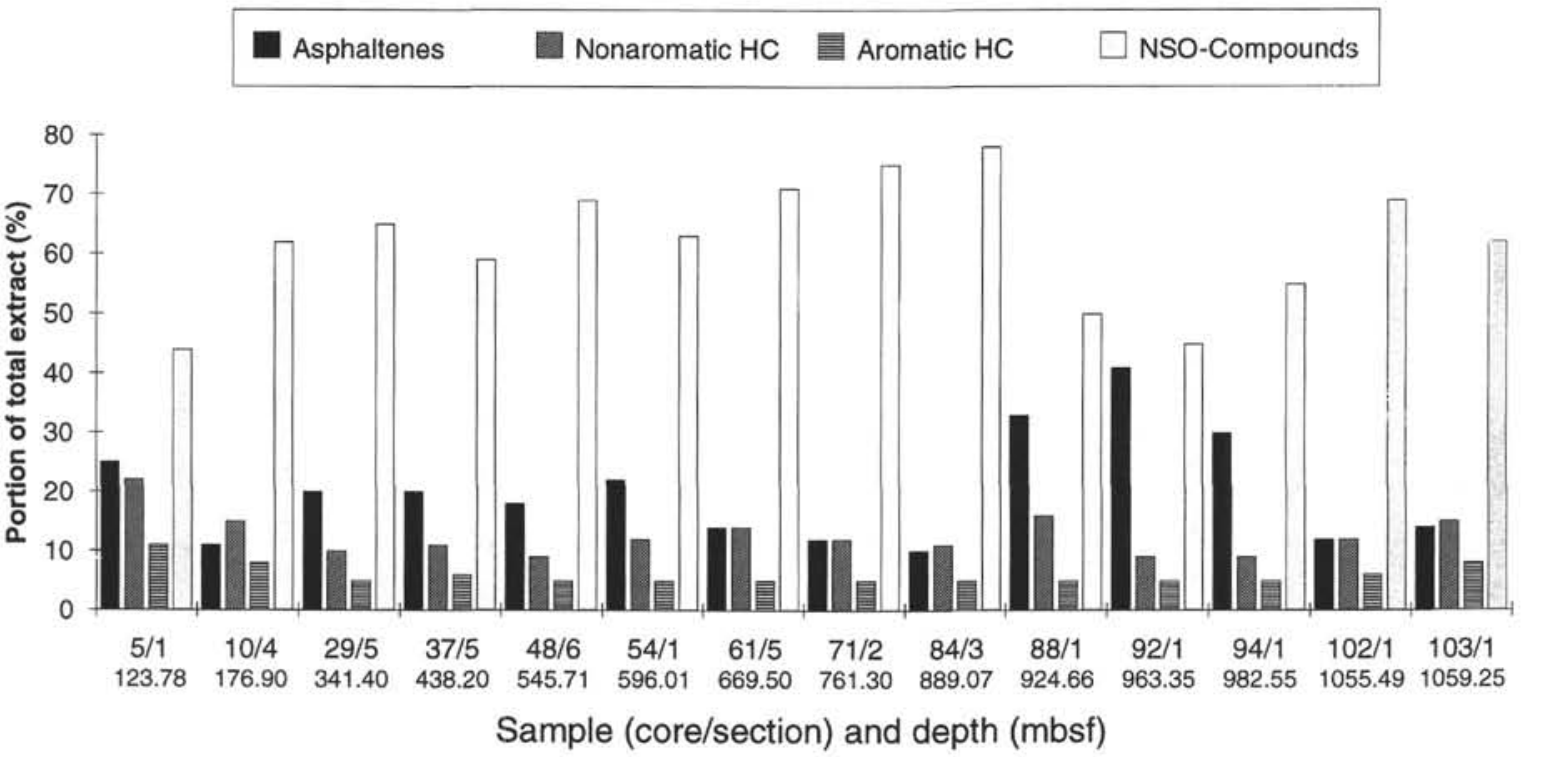

Figure 2. Relative proportions of gross fractions in the solvent-extractable organic matter of sediments from Hole $909 \mathrm{C}$. 

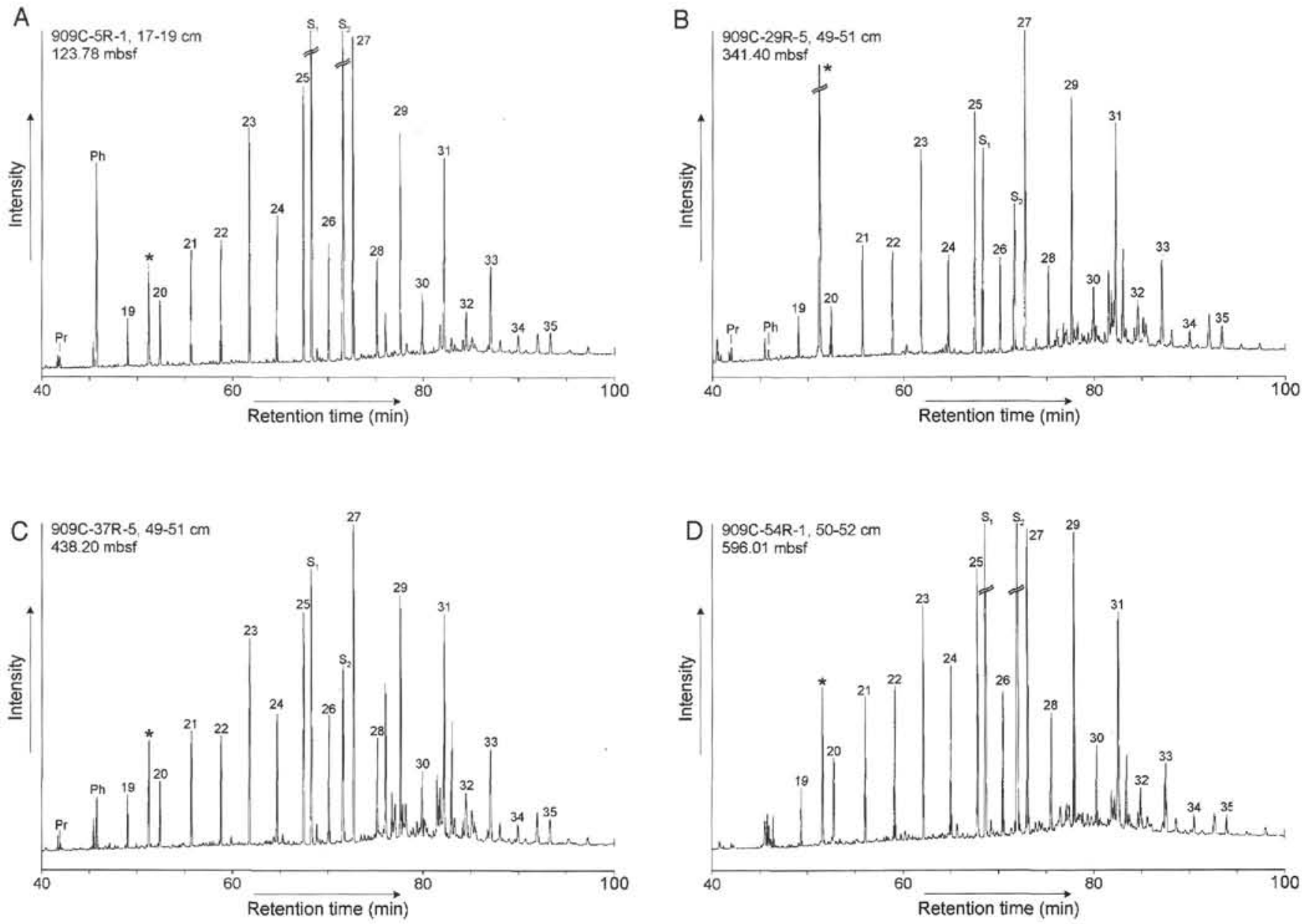

Figure 3. A-H. Partial capillary column gas chromatograms of the nonaromatic hydrocarbon fractions of eight selected sediment samples from Hole $909 \mathrm{C}$. Numbers indicate $n$-alkanes. $\mathrm{Pr}=$ pristane, $\mathrm{Ph}=$ phytane, $\mathrm{a}=17 \alpha(\mathrm{H})$-24, 28-dinor-lupane, $\mathrm{b}=17 \beta(\mathrm{H})$-24, 28-dinor-lupane, $\mathrm{c}=$ olean-12-ene, $\mathrm{d}=\mathrm{urs}$-12-ene, $\mathrm{S}_{1}$ $=$ behenic acid methyl ester (injection standard), $\mathrm{S}_{2}=$ squalane (internal standard), and ${ }^{*}=$ dibutyl phthalate (plasticizer contaminant).

imum in the distribution occurs at $n-\mathrm{C}_{27}$ at shallower depth and moves to $n-\mathrm{C}_{29}$ in sediments below a depth of about 550 mbsf. This may indicate a warmer climate (or supply of organic matter from a continental area with a warmer climate) in Miocene times. A strong predominance of the $n$-alkane homologs with odd carbon numbers, without any significant change with increasing depth, is another indication that thermal cracking has not been effective in the deepest sediments drilled.

\section{Isoprenoid Alkanes}

The abundance of the isoprenoid hydrocarbons pristane and phytane relative to the $n$-alkanes and their molecular ratios vary strongly within the sediments selected for this study (Fig. 3; Table 2). Samples 151-909C-5R-1, 17-19 cm (123.78 mbsf), and 37R-5, 49-51 cm (438.20 mbsf), show a strong predominance of phytane over pristane in a range that is commonly considered typical of hypersaline environments (ten Haven et al., 1987). There is no straightforward explanation for the unusually low pristane/phytane ratio in these two samples. The other sediments show a slight or significant pristane dominance over phytane, which is more in line with a dominance of higher-plant-derived organic matter. There is an increase in the pristane and phytane concentrations relative to the $n$-alkanes in sediments below about $700 \mathrm{mbsf}$, which is attributed to a progress in diagenetic conversion of functionalized precursors to saturated hydro- carbons, although slightly better preservation of labile organic matter may have also contributed to this downhole increase in relative concentrations of isoprenoid hydrocarbons.

\section{Steroid Hydrocarbons}

The depth ranges of the occurrence of different classes of steroid hydrocarbons are illustrated in Figure 4. Regular sterenes are restricted to the depth range of about 300 to $600 \mathrm{mbsf}$ as pairs of ster-4-and -5-enes with a slight predominance of the former isomer as expected from relative thermodynamic stabilities (de Leeuw et al., 1989). Ster2-enes are present in the shallowest sample studied. In Samples 151909C-5R-1, 17-19 cm, and 10R-4, 49-51 cm, the $\mathrm{C}_{27}$ to $\mathrm{C}_{29}$ carbon number ratio of the regular sterenes is about $1: 5$, whereas it is close to $1: 2$ in the deeper samples. In all cases, this indicates a dominance of terrigenous organic matter in the sediments (Huang and Meinschein, 1979), possibly with slightly better preservation of a marine component before the Pliocene.

Regular sterenes are diagenetically hydrogenated to the corresponding saturated steranes below about $700 \mathrm{mbsf}$ in Hole 909C (Fig. 4). The carbon number distribution corresponds to that of the sterenes in sediments from about 400 to $600 \mathrm{mbsf}$. Sterane formation in Hole $909 \mathrm{C}$ reflects the high geothermal heat flow of about $90^{\circ} \mathrm{C}$ (see Introduction). This value appears to be in the range of that in the California Borderland $\left(70^{\circ}-154^{\circ} \mathrm{C} / \mathrm{km}\right.$; Shipboard Scientific Party, 1981) 

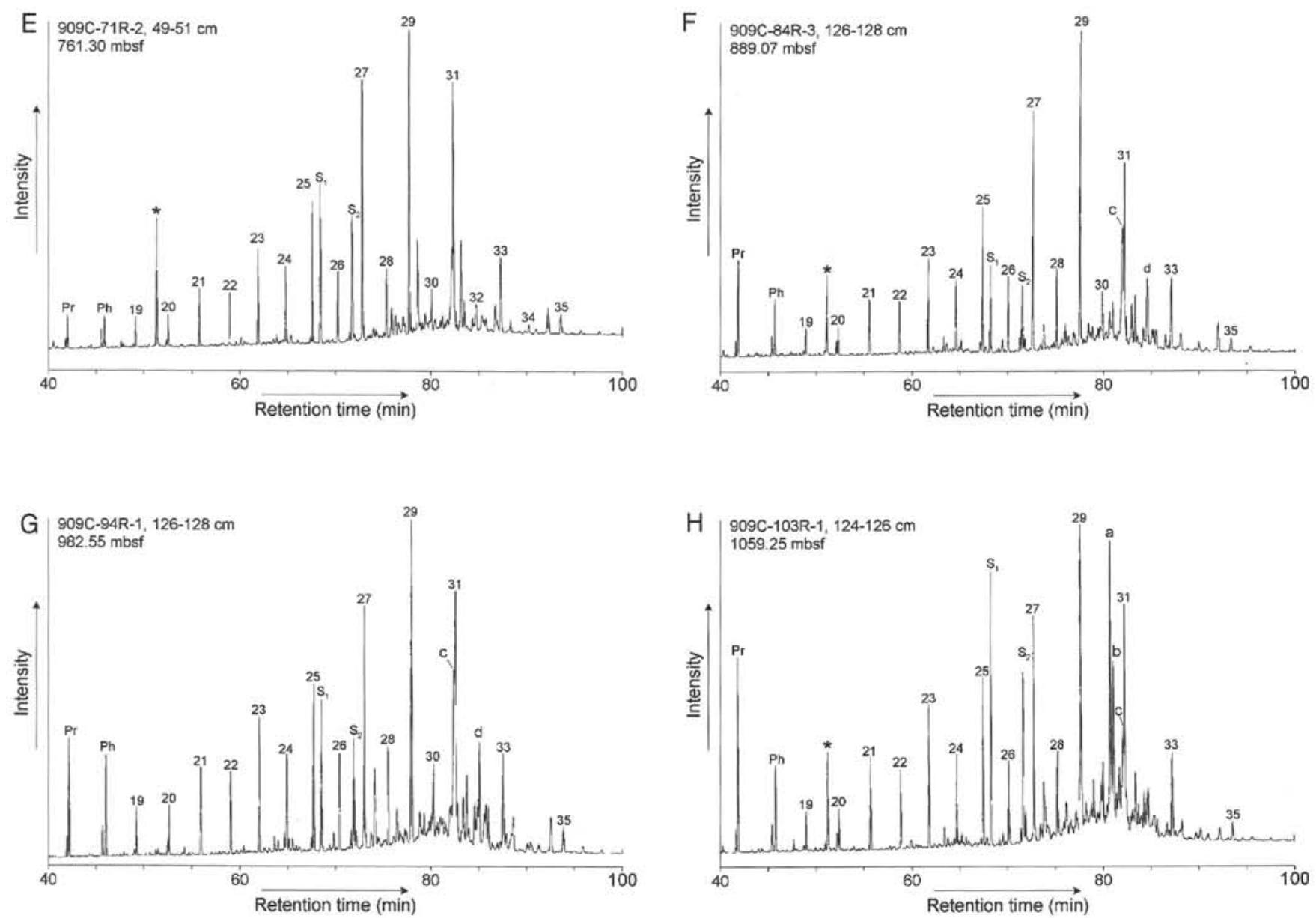

Figure 3 (continued).

where sterenes are completely transformed into steranes at a few hundred meters sub-bottom depth in middle Miocene sediments (Rullkötter and Welte, 1983). In contrast to this, the sterane/(sterane + sterene)-ratio has reached only a value of about 0.4 at $1200 \mathrm{mbsf}$ in early Miocene sediments on the relatively cool northwest African continental margin off Morocco (Rullkötter and Welte, 1983); a geothermal gradient of $36^{\circ}-44^{\circ} \mathrm{C} / \mathrm{km}$ was calculated for this area by Yükler et al. (1979) using a deterministic model. In Samples 151909C-102R-1, 128-130 cm, and 103R-1, 124-126 cm, the two deepest sediments studied from Hole 909C, there are already small amounts of the thermodynamically more stable 20S epimers (about $10 \%$ of the steranes with the biogenic $20 \mathrm{R}$ configuration). Very small amounts of regular steranes in shallow sediments from Hole 909C (Fig. 4) are believed to represent the supply of eroded sediment with more mature organic matter.

Diaster-13(17)-enes were found in all sediments from Hole 909C. Although their abundance in the shallower sediments is relatively low and their occurrence may be (mainly?) related to recycled organic matter, they are major polycyclic nonaromatic hydrocarbons below a depth of about 400 mbsf. Obviously, diagenetic rearrangement of sterenes by clay catalysis (Rubinstein et al., 1975; Sieskind et al., 1979) is a prominent diagenetic reaction of steroids in these sediments; this is in accordance with the lithologic composition (Table 1). Downhole diagenetic progress is obvious from the increase of the 20S/20R epimer ratio of the $\mathrm{C}_{27}$ diasterenes (Table 2). The value of about $45 \% 20 \mathrm{~S}$ epimer for the deepest samples exceeds those of Cretaceous deep-sea sediments from the Falkland Plateau $(<30 \% 20 \mathrm{~S}$ epimer at $625 \mathrm{mbsf}$ ) and the Moroccan Basin (about $43 \%$ at 1350 mbsf; Brassell et al., 1984) and again reflects the high geothermal heat flow in the Fram Strait. The same is true for the occurrence of saturated diasteranes, formed from diasterenes by hydrogenation, in the two deepest samples studied at Site 909. This process is known to take place close to the diagenesis/catagenesis boundary (Mackenzie et al., 1982; Brassell, 1985).

\section{Higher Plant Triterpenoids}

Oleanenes with olean-12-ene as the most prominent isomer and urs-12-ene are common constituents of the sediments below about $400 \mathrm{mbsf}$ (Fig. 4). They are particularly abundant in the deepest sediments studied (Fig. 3F-H). In addition, 24,28-dinor-17 $\alpha$ - and $-17 \beta$ lupane epimers were detected in Samples 151-909C-94R-1, 124-126 $\mathrm{cm}$, and 103R-1, 124-126 cm, and these compounds are major nonaromatic hydrocarbon constituents in the latter sample (Fig. $3 \mathrm{H}$ ) where they almost match the concentration of the most abundant $n$ alkane. Triterpenoids of higher land-plant origin were detected before in great abundance in deep-sea sediments from the Baffin Bay west of Greenland (ten Haven and Rullkötter, 1989; ten Haven et al., 1992). 24,28-dinor-Lupanes were first described to occur in sediments of Paleocene age from West Greenland (Rullkötter et al., 1982) and were later found in oils and source rocks from the offshore Beaufort-Mackenzie Delta area in northern Canada (Brooks, 1986; Peakman et al., 1991). The frequent occurrence of the dinor-lupanes and other terrigenous triterpenoids in this part of the northern hemisphere explains their occurrence in the Fram Strait sediments, but the varying amounts also indicate that contribution of continental material 


\section{Type of biomarker}

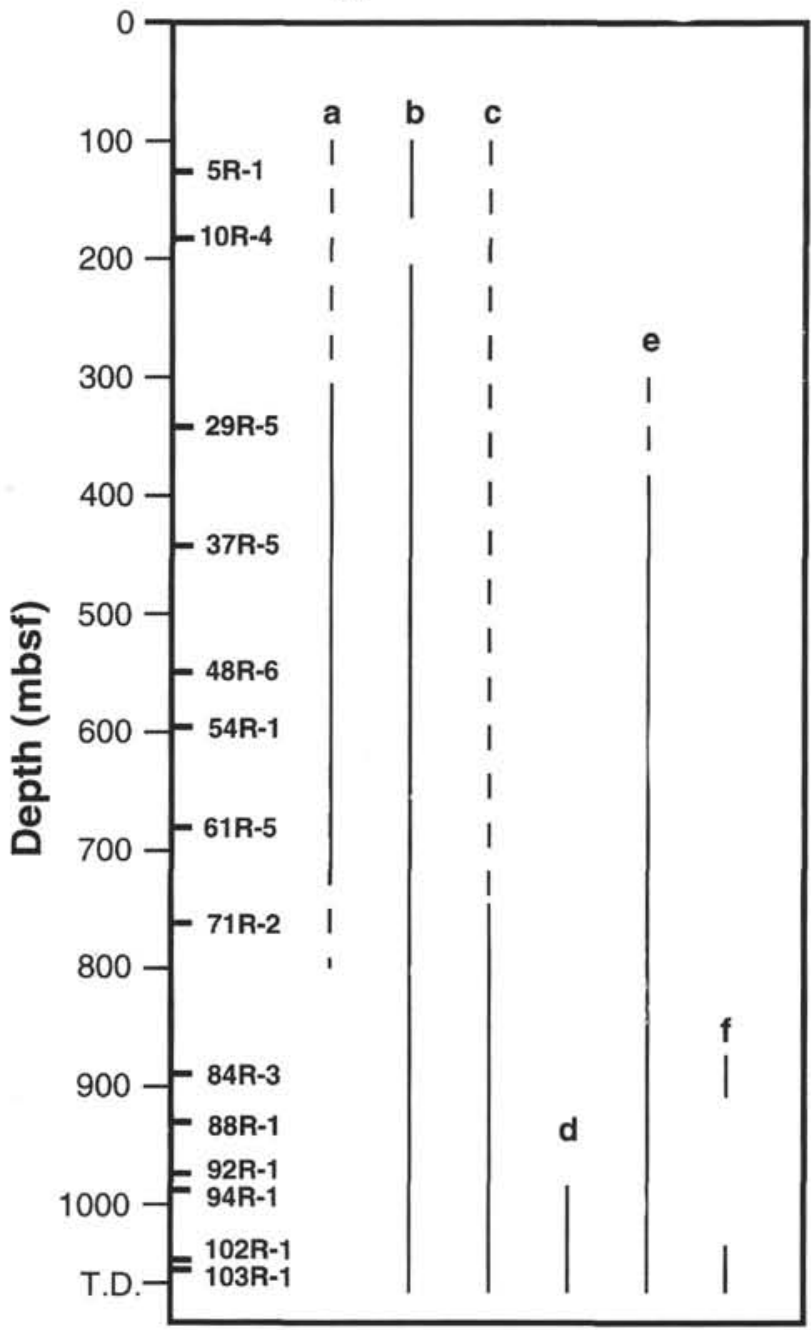

Figure 4. Depth ranges of the occurrence of various groups of biological markers in Hole 909C sediments. $\mathrm{a}=$ regular sterenes, $\mathrm{b}=$ diasterenes, $\mathrm{c}=$ regular steranes, $d=$ diasteranes, $e=$ oleanenes, and $f=24,28$-dinor-lupanes. Broken lines indicate very low abundance.

was not constant with time. A higher resolution study would be needed to use the occurrence of terrigenous triterpenoid hydrocarbons and, potentially, their oxygenated derivatives to define this source parameter more precisely.

\section{Bacterial Hopanoids}

Hopanoid hydrocarbons, probably mostly of bacterial origin, are common in all sediments from Hole 909C. Their distribution patterns are highly variable, however, as shown by the $\mathrm{m} / \mathrm{z} 191$ mass chromatograms of three selected samples in Figure 5. The dominance of hop-17(21)-ene over the isomeric neo-hop-13(18)-ene in the shallower sediments abruptly changes at about $800 \mathrm{mbsf}$ (Table 2). Higher stability of the neo-hopene isomer and/or direct transformation of hop-17(21)-ene into neo-hop-13(18)-ene by isomerization may be the reasons for this diagenetic alteration of the hopanoid hydrocarbon pattern. Another diagenetic progress is represented by the virtual dis-

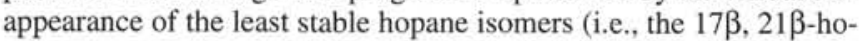
panes), in the deepest sample from Hole 909C (Fig. 5C). In contrast to this, the C-22 epimer ratio of the 30 -homo-17 $\alpha$-hopanes does not change systematically with depth within the samples series studied (Table 2). Apparently, the temperatures are not high enough for isomerization of the extended 17 $\alpha$-hopanes, and the small amounts of the $22 \mathrm{~S}$ epimer arise from hydrogenation of unsaturated hopenes, possibly directly inherited from microorganisms.

\section{CONCLUSIONS}

Nonaromatic hydrocarbons form only a minor part of the extractable organic matter of sediments with immature organic matter, and the analysis of only this fraction has admittedly been found to be misleading in organofacies assessment of deep-sea sediments in certain cases (ten Haven et al., 1990). However, the dominance of terrigenous organic matter indicated by both Rock-Eval pyrolysis (Shipboard Scientific Party, 1995) and biological marker composition and the fact that the progress in diagenesis will already have led to a substantial transformation of functionized lipids into hydrocarbons (at least in the deeper sediments from Hole 909C) are a solid basis for concluding that marine organic matter plays only a subordinate role in the Fram Strait sediments. Terrigenous organic matter supply varied with time, however, as deduced from the variable distribution of the terrigenous triterpenoid hydrocarbons. With the information presently available. it cannot be decided if there were paleoceanographic reasons or if climatic variations caused changes of the continental vegetation in the source region(s).

Biological marker distribution patterns and compound ratios clearly show that high geothermal heat flow causes rapid progress in diagenesis comparable to that, for example, of the California Borderland. Nevertheless, although there appears to be an approach to the diagenesis-catagenesis boundary, the onset of thermal hydrocarbon generation by kerogen cracking was not reached in Hole 909C. Thus, the high concentrations of volatile hydrocarbons detected during drilling most likely represent mainly migrated material from greater depth, although part of them may derive from in situ, low-temperature diagenesis as observed in other deep-sea sediments (e.g., Schaefer and Leythaeuser, 1984; Shipboard Scientific Party, 1984)

\section{ACKNOWLEDGMENTS}

We would like to thank Dr. Eric Lichtfouse (Université Marie et Pierre Curie, Paris) and an anonymous referee for their thorough reviews and helpful suggestions. Financial support by the Deutsche Forschungsgemeinschaft (Bonn), grant Ste $412 / 7$, is gratefully acknowledged.

\section{REFERENCES}

Brassell, S.C., 1985. Molecular changes in sediment lipids as indicators of systematic early diagenesis. Philos. Trans. R. Soc. London A, 315:57-75.

Brassell, S.C., McEvoy, J., Hoffmann, C.F., Lamb, N.A., Peakman, T.M., and Maxwell, J.R., 1984. Isomerization, rearrangement and aromatisation of steroids in distinguishing early stages of diagenesis. $\ln$ Schenck, P.A., de Leeuw, J.W., and Lijmbach, G.W.M. (Eds.), Advances in Organic Geochemistry 1983: Oxford (Pergamon Press), 1123.

Brooks, P.W., 1986. Unusual biological marker geochemistry of oils and possible source rocks, offshore Beaufort-Mackenzie Delta, Canada. In Leythaeuser, D., and Rullkötter, J. (Eds.), Advances in Organic Geochemistry 1985: Oxford (Pergamon Press), 401-406.

de Leeuw, J.W., Cox, H.C., van Graas, G., van de Meer, F.W., Peakman, T.M., Baas, J.M.A., and van de Graaf, B., 1989. Limited double bond isomerisation and selective hydrogenation of sterenes during early diagenesis. Geochim. Cosmochim. Acta, 53:903-909.

Eglinton, G., Hamilton, R.J., Raphael, R.A., and Gonzalez, A.G., 1962 Hydrocarbon constituents of the wax coatings of plant leaves: a taxonomic survey. Nature, 193:739-742. 
Huang, W.-Y., and Meinschein, W.G., 1979. Sterols as ecological indicators. Geochim. Cosmochim. Acta, 43:739-745.

Lichtfouse, É., Derenne, S., Mariotti, A., and Largeau, C., 1994. Possible algal origin of long chain odd $n$-alkanes in immature sediments as revealed by distributions and carbon isotope ratios. Org. Geochem. 22:1023-1027.

Mackenzie, A.S., Brassell, S.C., Eglinton, G., and Maxwell, J.R., 1982. Chemical fossils: the geological fate of steroids. Science, 217:491-504.

Peakman, T.M., ten Haven, H.L., Rullkötter, J., and Curiale, J.A., 1991 Characterisation of 24-nor-triterpenoids occurring in sediments and crude oils by comparison with synthesized standards. Tetrahedron, 47:3779-3786.

Radke, M., Willsch, H., and Welte, D.H., 1980. Preparative hydrocarbon group type determination by automated medium pressure liquid chromatography. Anal. Chem., 52:406-411.

Rubinstein, I., Sieskind, O., and Albrecht, P., 1975. Rearranged sterenes in a shale: occurrence and simulated formation. J. Chem. Soc., Chem. Com. mun.: 957-958.

Rullkötter, J., Leythaeuser, D., and Wendisch, D., 1982. Novel 23,28-bisnorlupanes in Tertiary sediments: widespread occurrence of nuclear demethylated triterpanes. Geochim. Cosmochim. Acta, 46:2501-2509.

Rullkötter, J., von der Dick, H., and Welte, D.H., 1981. Organic petrography and extractable hydrocarbons of sediments from the eastern North Pacific Ocean, Deep Sea Drilling Project Leg 63. In Yeats, R.S., Haq, B.U., et al., Init. Repts. DSDP, 63: Washington (U.S. Govt. Printing Office), 819836.

Rullkötter, J., and Welte, D.H., 1983. Maturation of organic matter in areas of high heat flow: a study of sediments from DSDP Leg 63, offshore California, and Leg 64, Gulf of California. In Bjoroey, M., Albrecht, C., Cornford, C., de Groot, K., Eglinton, G., Galimov, E., Leythaeuser, D. Pelet, R., Rullkötter, J., and Speers, G. (Eds.), Advances in Organic Geochemistry 1981: Chichester (Wiley), 438-448.

Schaefer, R.G., and Leythaeuser, D., 1984. $\mathrm{C}_{2}-\mathrm{C}_{8}$ hydrocarbons in sediments from Deep Sea Drilling Project Leg 75, Holes 530A, Angola Basin, and 532, Walvis Ridge. In Hay, W.W., Sibuet, J.-C., et al., Init. Repts. DSDP, 75 (Pt. 2): Washington (U.S. Govt. Printing Office), 1055-1067.

Shipboard Scientific Party, 1981. Site 471: offshore Magdalena Bay. In Yeats, R.S., Haq, B.U., et al., Init. Repts. DSDP, 63: Washington (U.S. Govt. Printing Office), 269-349.
1984. Site 545. In Hinz, K., Winterer, E.L., et al., Init. Repts. DSDP, 79: Washington (U.S. Govt. Printing Office), 81-177.

1995. Site 909. In Myhre, A.M., Thiede, J., Firth, J.V., et al., Proc. ODP, Init. Repts., 151: College Station, TX (Ocean Drilling Program), 159-220.

Sieskind, O., Joly, G., and Albrecht, P., 1979. Simulation of the geochemical transformation of sterols: superacid effects of clay minerals. Geochim. Cosmochim. Acta, 43:1675-1679.

Stein, R., Brass, G., Graham, D., Pimmel, A., and the Shipboard Scientific Party, 1995. Hydrocarbon measurements at Arctic Gateways sites (ODP Leg 151). In Myhre, A.M., Thiede, J., Firth, J.V., et al., Proc. ODP, Init. Repts., 151: College Station, TX (Ocean Drilling Program), 385-395.

ten Haven, H.L., de Leeuw, J.W., Rullkötter, J., and Sinninghe Damsté, J.S., 1987. Restricted utility of the pristane/phytane ratio as a paleoenvironmental indicator. Nature, 330:641-643.

ten Haven, H.L., Littke, R., Rullkötter, J., Stein, R., and Welte, D.H., 1990. Accumulation rates and composition of organic matter in late Cenozoic sediments underlying the active upwelling area off Peru. In Suess, E., von Huene, R., et al., Proc. ODP, Sci. Results, 112: College Station, TX (Ocean Drilling Program), 591-606.

ten Haven, H.L., Peakman, T.M., and Rullkötter, J., 1992. Early diagenetic transformation of higher plant triterpenoids in deep sea sediments from Baffin Bay. Geochim. Cosmochim. Acta, 56:2001-2024.

ten Haven, H.L., and Rullkötter, J., 1989. Oleanene, ursene, and other terrigenous triterpenoid biological-marker hydrocarbons in Baffin Bay sediments. In Srivastava, S.P., Arthur, M.A., Clement, B., et al., Proc. ODP, Sci. Results, 105: College Station, TX (Ocean Drilling Program), 233242.

Yükler, M.A., Cornford, C., and Welte, D.H., 1979. Simulation of geologic, hydrodynamic, and thermodynamic development of a sediment basin: a quantitative approach. In von Rad, U., Ryan, W.B.F., et al., Init. Repts. DSDP, 47 (Pt. 1): Washington (U.S. Govt. Printing Office), 761-771.

Date of initial receipt: 4 August 1995

Date of acceptance: 20 November 1995

Ms 151SR-144 

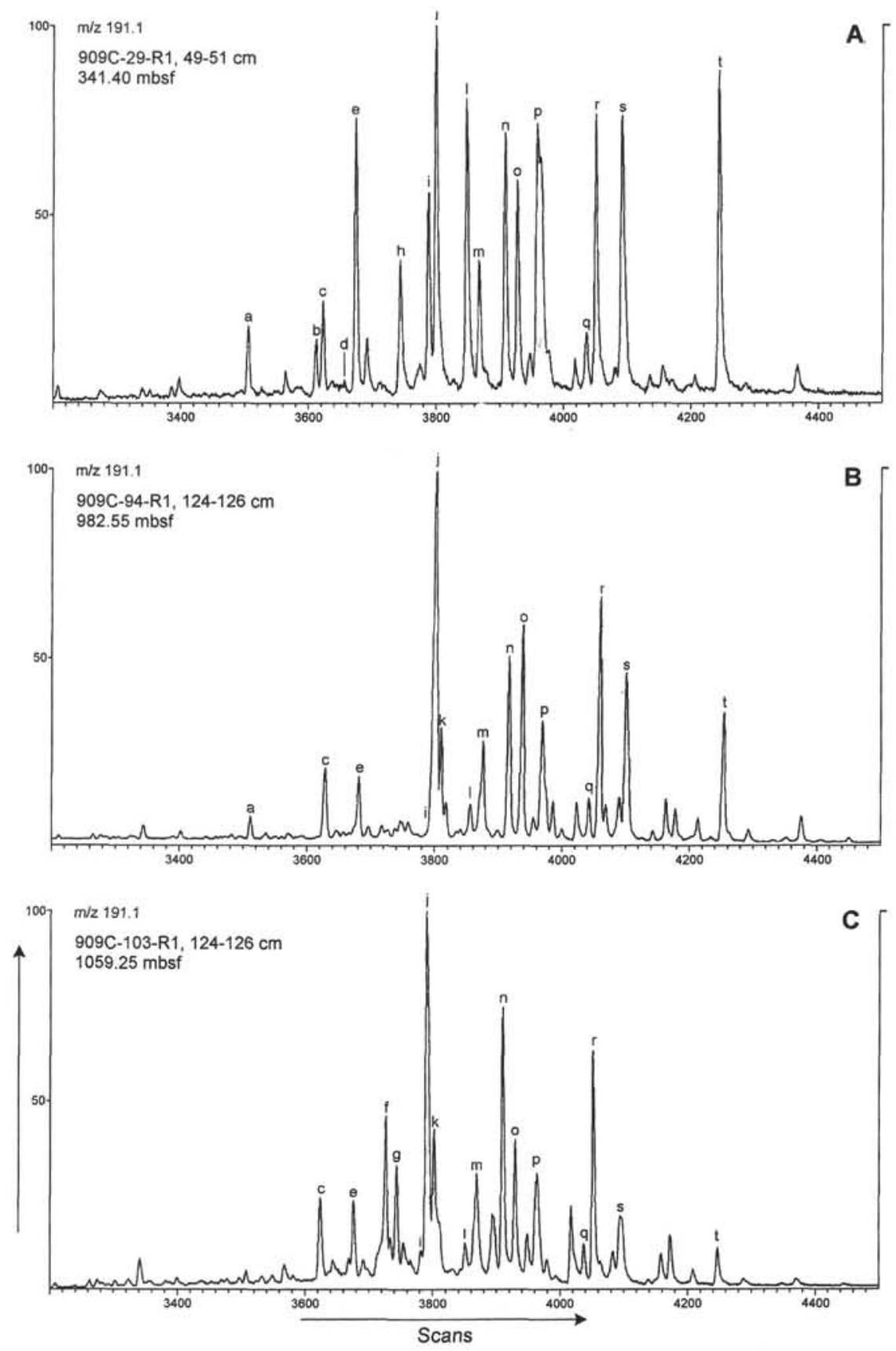

Figure 5. A-C. M/z 191 mass fragmentograms typical of pentacyclic triterpenoid hydrocarbons for three selected sediments from Hole 909C. See Table 1 for complete sample codes. $\mathrm{a}=22,29,30$-trinor-neo-hop-13(18)-ene, $\mathrm{b}=22,29,30$-trinor- hop-17(21)-ene, $\mathrm{c}=22,29,30$-trinor-17 $\alpha$-hopane, $\mathrm{d}=25,28,30$-trinor$17 \alpha, 18 \alpha$-hopane (position indicated), $\mathrm{e}=22,29,30$-trinor-17 $\beta$-hopane, $\mathrm{f}=24,28$-dinor-17 $\alpha$-lupane, $\mathrm{g}=24,28$-dinor-17 $\beta$-lupane, $\mathrm{h}=28,30$-dinor-17 $\alpha, 18 \alpha$ -

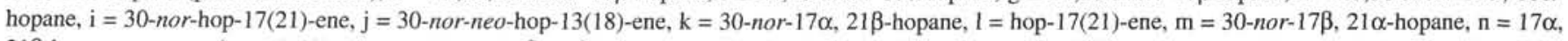

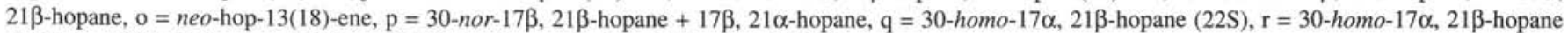
(22R), $\mathrm{s}=17 \beta, 21 \beta$-hopane +30 -homo-17 $\beta, 21 \alpha$-hopane, and $\mathrm{t}=30$-homo-17 $\beta, 21 \beta$-hopane. 